Primljen / Received: 17.9.2013. Ispravljen / Corrected: 28.1.2014.

Prihvaćen / Accepted: 21.2.2014.

Dostupno online / Available online: 10.4.2014.

\section{Temperature effect on compression and collapsibility of residual granitic soil}

\section{Authors:

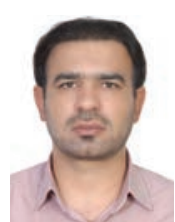

Mehrdad Kholghifard, PhD. CE University Technology Malaysia Faculty of Civil Engineering Islamic Azad University,Yasouj Branch,,ran Kholghifard.m@gmail.com

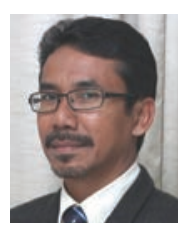

Assoc.Prof. Kamarudin Ahmad University Technology Malaysia Faculty of Civil Engineering kamarudin@utm.my
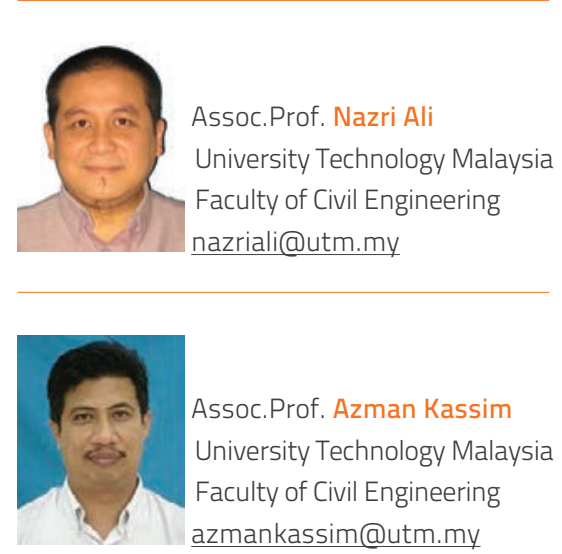

Assoc.Prof. Azman Kassim University Technology Malaysia Faculty of Civil Engineering azmankassim@utm.my

Roohollah Kalatehjari, PhD. CE University Technology Malaysia Faculty of Civil Engineering kalatehjary@yahoo.com

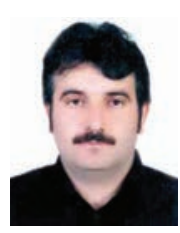

Farzad Babakanpour, MSc. CE Municipality of Yasouj, Iran babkan.saverz@yahoo.com

\section{Kholghifard, K. Ahmad, N. Ali, A. Kassim, R. Kalatehjari, F. Babakanpour}

\section{Temperature effect on compression and collapsibility of residual granitic soil}

This research aims to investigate the effect of temperature changes on the compression index and collapse potential of the residual granitic soil that is widely encountered in Malaysia. An experimental study was conducted on the compacted soil using a modified temperaturecontrolled oedometer. Temperatures of 27,40 , and $60^{\circ} \mathrm{C}$ were applied on two series of soil specimens with different values of dry density. Experimental results showed that the value of compression index is independent of temperature. On the other hand, heating caused a reduction in collapse potential, which was more pronounced at low dry density.

Key words:

Temperature, Compression index, Collapse potential, Residual granitic soils

Izvorni znanstveni rad

M. Kholghifard, K. Ahmad, N. Ali, A. Kassim, R. Kalatehjari, F. Babakanpour

\section{Utjecaj temperature na stišljivost i potencijal kolapsibilnosti rezidualnog granitnog tla}

U ovom se radu istražuje utjecaj temperaturnih promjena na indeks stišljivosti i potencijal kolapsibilnosti rezidualnog granitnog tla na koje se često nailazi u Maleziji. Zbijeno tlo analizirano je pomoću modificiranog edometra s kontrolom temperature. Dvije serije uzoraka tla s raznim vrijednostima suhe gustoće ispitane su pri temperaturama od 27,40 i $60^{\circ} \mathrm{C}$. Rezultati ispitivanja pokazuju da vrijednost indeksa stišljivosti ne ovisi o temperaturi. S druge strane, grijanje dovodi do smanjenja potencijala kolapsibilnosti, a ta je pojava izraženija pri niskim vrijednostima suhe gustoće.

Ključne riječi:

temperatura, indeks stišljivosti, potencijal kolapsibilnosti, rezidualna granitna tla

Wissenschaftlicher Originalbeitrag

M. Kholghifard, K. Ahmad, N. Ali, A. Kassim, R. Kalatehjari, F. Babakanpour

\section{Temperatureinflüsse auf die Kompressibilität und Kollapsibilität von residualen Granitböden}

In dieser Arbeit wird der Einfluss von Temperaturveränderungen auf den Kompressibilitätsmodul und das Kollapspotenzial in Malaysia häufig vorkommender residualer Granitböden untersucht. Proben verdichteten Bodens sind mittels eines modifizierten Ödometers mitTemperaturkontrolle analysiert worden. Zwei Versuchsserien mit Bodenproben verschiedener Trockendichten sind für Temperaturwerte von 27,40 und $60^{\circ} \mathrm{C}$ durchgeführt worden. Die Resultate haben gezeigt, dass der Kompressibilitätsmodul nicht von der Temperatur abhängt. Andererseits führt ein Temperaturanstieg zur Reduktion des Kollapspotenzials, und diese Erscheinung istausgeprägter für niedrige Werte der Trockendichte..

Schlüsselwörter:

Temperatur, Kompressibilitätsmodul, Kollapspotenzial, residuale Granitböden 


\section{Introduction}

Over the past two decades, geotechnical engineers have been increasingly examining thermal influences on physical and mechanical properties of soil. Firstly, researchers attempted to explain the influence of temperature changes on the volumetric and strength parameters of soil samples through experimental studies [1, 2]. Therefore, earlier research mostly focused on engineering properties of soil at temperatures of less than $50{ }^{\circ} \mathrm{C}$. Present-day activities relating to geotechnics, such as the storage of nuclear waste, deep offshore well drilling, and foundations subjected to temperature changes, have led researchers to study the thermo-mechanical behavior of soils at temperatures of up to $100^{\circ} \mathrm{C}$ and above.

Several researchers [3-6] have explored thermal effects on the physical and mechanical behavior of clayey soils. A general outcome of these studies is that an increase in temperature induces a decrease in the void ratio of normally consolidated soil, whereas warming may cause swelling in overconsolidated soils. These studies also show that the thermal volumetric behavior of unsaturated soils is influenced by the overconsolidation ratio and suction.

On the other hand, the hydro-mechanical behavior of heavily compacted clayey soils surrounding waste disposal zones are considerably influenced by the long term elevation in temperature $[7,8]$. Francois \& Laloui [8] point to a slight reduction in water retention capacity of soil due to increase in temperature. Cekerevac and Laloui [4] study the thermo-mechanical behavior of some artificial clayey soils to assess their use as a buffer for nuclear waste containers. They claim that an increase in temperature of a saturated soil to less than the boiling point of water $\left(100^{\circ} \mathrm{C}\right)$ impacts the volume change, shear strength, and stiffness of soil.

Over the past fifty years, many studies have been conducted to evaluate parameters affecting the collapse potential of compacted soils [6, 9-11]. However, literature review shows that no data is currently available about the effects of temperature on the collapse potential of the residual granitic soil. Thus, results obtained by experimental study of temperature effects on the compression index and collapse potential of the residual granitic soil are presented in this paper.

\section{Materials and methods}

\subsection{Basic properties of the soil}

The reddish brown residual granitic soil samples for this study were collected from the depth of $1.7 \mathrm{~m}$ at the Universiti Teknologi Malaysia (UTM) campus. Classification tests employed according to BS1377: Part 2 [12] revealed that the soil is the silt of high plasticity, MH. In addition,
X-ray diffraction (XRD) analysis results indicated that the representative soil sample consists of quartz, mica and feldspar as its non-clay minerals, and kaolinite and montmorillonite as its clay minerals. Results of the standard Proctor compaction test applied to achieve maximum dry density of soil are shown in Figure 1. Some basic engineering properties of samples are presented in Table 1.

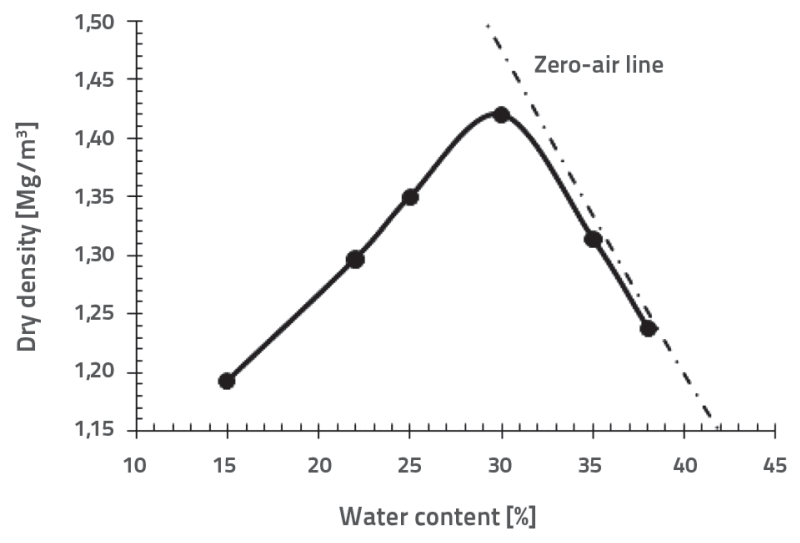

Figure 1. Compaction curve of residual granitic soil

Table 1. Basic properties of residual granitic soil

\begin{tabular}{|c|c|}
\hline Property & Value \\
\hline $\begin{array}{l}\text { Liquid Limit [\%] } \\
\text { Plastic Limit [\%] } \\
\text { Plasticity Index [\%] } \\
\text { Specific Gravity }\end{array}$ & $\begin{array}{c}68 \\
35 \\
33 \\
2,67\end{array}$ \\
\hline $\begin{array}{l}\text { Sieve Analysis and Hydrometer } \\
\text { Gravel [\%] } \\
\text { Sand }[\%] \\
\text { Silt }[\%] \\
\text { Clay }[\%]\end{array}$ & $\begin{array}{l}3 \\
36 \\
40 \\
21\end{array}$ \\
\hline $\begin{array}{l}\text { Optimum Moisture Content [\%] } \\
\text { Maximum Dry Density [Mg/m³] } \\
\text { Natural Dry Density }\left[\mathrm{Mg} / \mathrm{m}^{3}\right] \\
\text { Natural Water Content [\%] }\end{array}$ & $\begin{array}{c}30 \\
1,41 \\
1,21 \\
26\end{array}$ \\
\hline
\end{tabular}

\subsection{Preparation of compacted soil samples}

The air dried representative soil sample passing the $2 \mathrm{~mm}$ sieve was completely hand-blended at the designed water content of $30 \%$. The mixture was permitted to achieve equilibrium for 24 hours in a sealed plastic cover. The required mass of prepared wet soil samples was compacted to different dry densities using the hand-operated dynamic compaction process based on BS1377: Part 4 [13]. Characteristics of tested soil samples are summarized in Table 2. 
Table 2. Properties of prepared compacted samples

\begin{tabular}{|c|c|c|c|c|c|}
\hline $\begin{array}{c}\text { Specimen } \\
\text { (Series) }\end{array}$ & $\begin{array}{c}\text { Dry density } \\
{\left[\mathrm{Mg} / \mathrm{m}^{3}\right]}\end{array}$ & $\begin{array}{c}\text { Compaction } \\
{[\%]}\end{array}$ & $\begin{array}{c}\text { Initial water } \\
\text { content } \\
{[\%]}\end{array}$ & $\begin{array}{c}\text { Temperature } \\
{\left[{ }^{\circ} \mathrm{C}\right]}\end{array}$ & $\begin{array}{c}\text { Initial void } \\
\text { ratio }\end{array}$ \\
\hline A & 1,21 & 85 & 30 & $27 / 40 / 60$ & 1,21 \\
\hline B & 1,35 & 95 & 30 & $27 / 40 / 60$ & 1,03 \\
\hline
\end{tabular}

\subsection{Test performance}

This experimental study consisted of a series of double oedometer tests conducted on soil specimens under various values of temperature at different initial dry densities. A modified oedometer shown in Figure 2 was used for the testing.

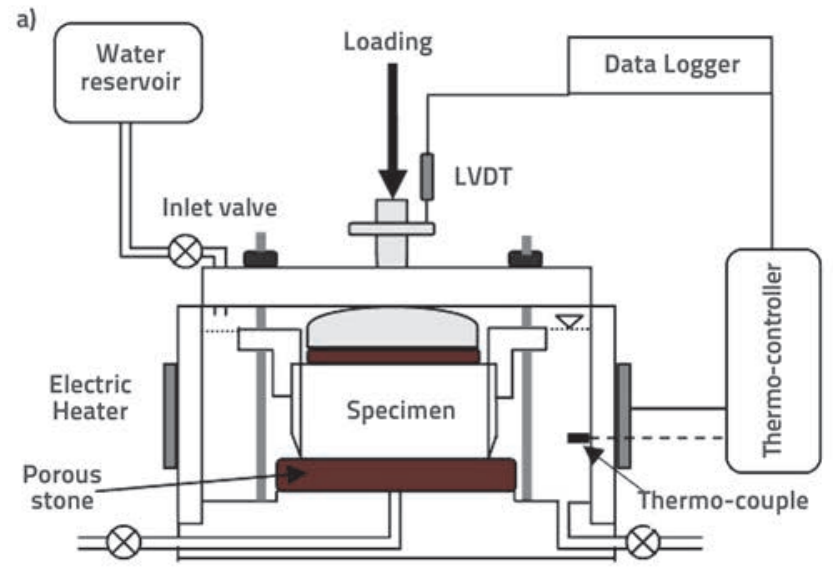

$$
\text { Outlet valve }
$$

Outlet valve

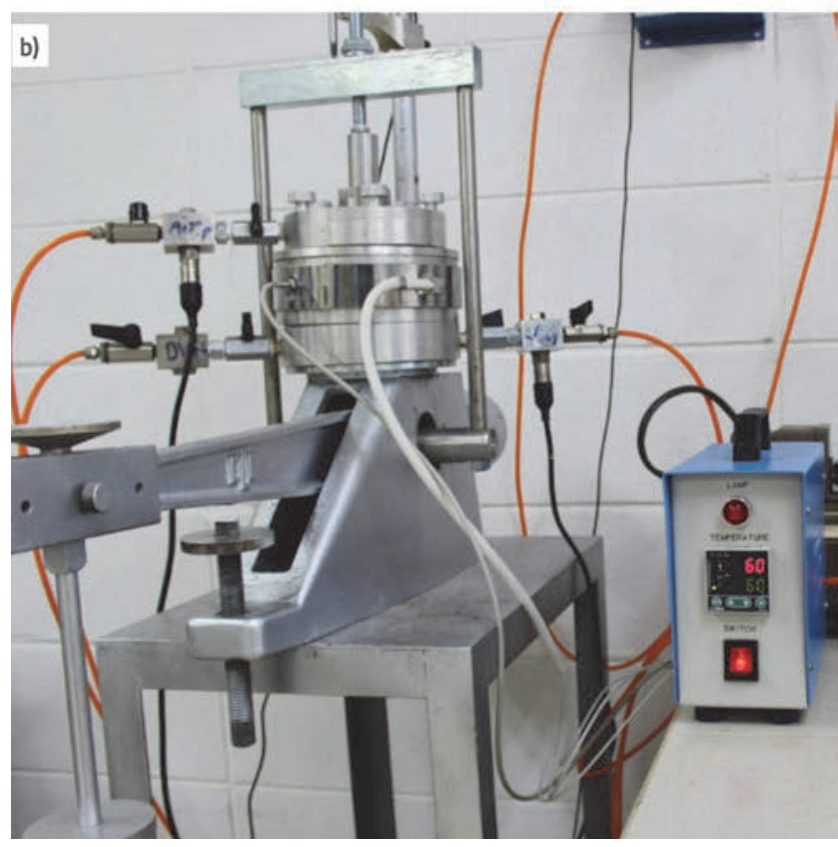

Figure 2. Modified oedometer: a) schematic diagram; b) photograph
The modified oedometer consisted of a conventional oedometer device, a ring-shaped heater with an external oedometer ring, a thermocouple, a water tank, and a thermocontroller unit. In addition, the conventional oedometer device was customized by means of a temperature chamber which was connected to the thermo-controller unit accurate to $\pm 1{ }^{\circ} \mathrm{C}$. The thermo-controller was capable of controlling temperatures of up to $90^{\circ} \mathrm{C}$.

Double-oedometer tests [14] were carried out to determine the collapse potential of two series of the residual granitic soil samples. This method consists of two consolidation tests conducted on two identical specimens in each series. These identical specimens were placed in oedometers and kept at a low pressure ( $1 \mathrm{kPa})$. One of the specimens was initially fully saturated and kept at a low pressure (1 kPa) for $24 \mathrm{~h}$, after which the specimen was loaded up to $400 \mathrm{kPa}$ using the standard incremental loading procedure. The other specimen was incrementally loaded up to $400 \mathrm{kPa}$ at its initial water content without soaking. The difference in void ratios of the soaked and unsoaked specimens was considered as the collapse potential. For each series of specimens, the double-oedometer test was conducted at three different temperatures $\left(27,40\right.$, and $\left.60^{\circ} \mathrm{C}\right)$ using a modified oedometer. The soil specimen temperature was indirectly increased by heating the water in the annular space between the external ring of the oedometer and the specimen ring. The calibration test indicated that an average time required for the specific temperature maintained in the circular space to reach the center of the specimen was about $18 \mathrm{~min}$. As a result, the desired temperature must be kept for at least 20 min before beginning any test.

The collapse potential was determined at vertical stress levels of $25,50,100,200$, and $400 \mathrm{kPa}$ for all specimens. The collapse potential $\left(C_{p} \%\right)$ of the specimens was calculated using the following equation specified in ASTM D 5333 [15]:

$C_{p}(\%)=\left[\frac{e_{i}-e_{f}}{1+e_{0}}\right] \times 100 \%$

where $e_{0}$ is the initial void ratio, $e_{i}$ and $e_{f}$ are void ratio values obtained by oedometer tests at initial water content and in saturated condition, respectively, under the same vertical stress.

\section{Results and discussion}

Figures 3 and 4 show void ratio versus vertical stress graphs based on double-oedometer tests performed on samples of series $A$ and series $B$, respectively, at different temperatures. The intersection of the elastic compression slope and the plastic compression slope was defined as the preconsolidation stress as shown in Figure 3 and Figure 4. This method was also employed by Lloret et al. [16]. Table 3 presents the preconsolidation stress (at which yield occurs) for both groups in moist conditions. 


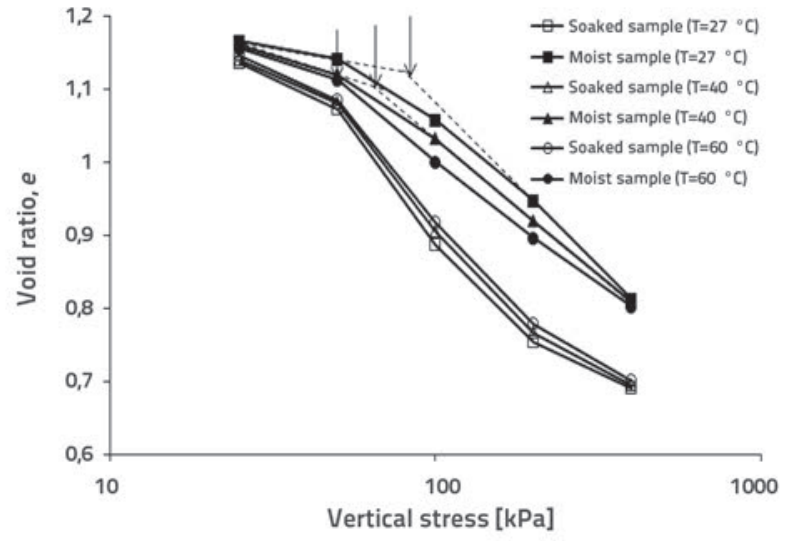

Figure 3. Compression curves for series A specimens

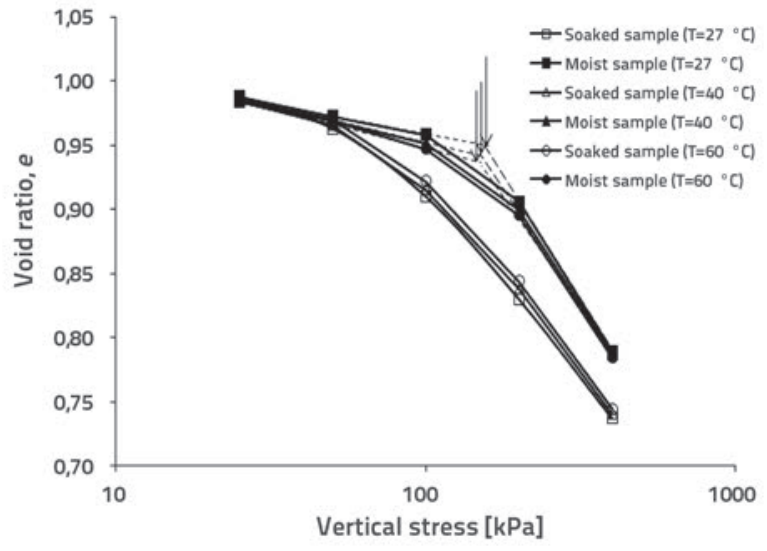

Figure 4. Compression curves for series B specimens

It can be noticed that the preconsolidation stress of soil specimens decreases with temperature. However, this was negligible for the denser specimen. A similar behavior for clay was reported by Cekerevac \& Laloui [4]. Approximately similar shapes of compression curves for each series were observed at different temperatures. In addition, the difference among the compression curves at different temperatures for the denser samples (series B) was insignificant because

a)

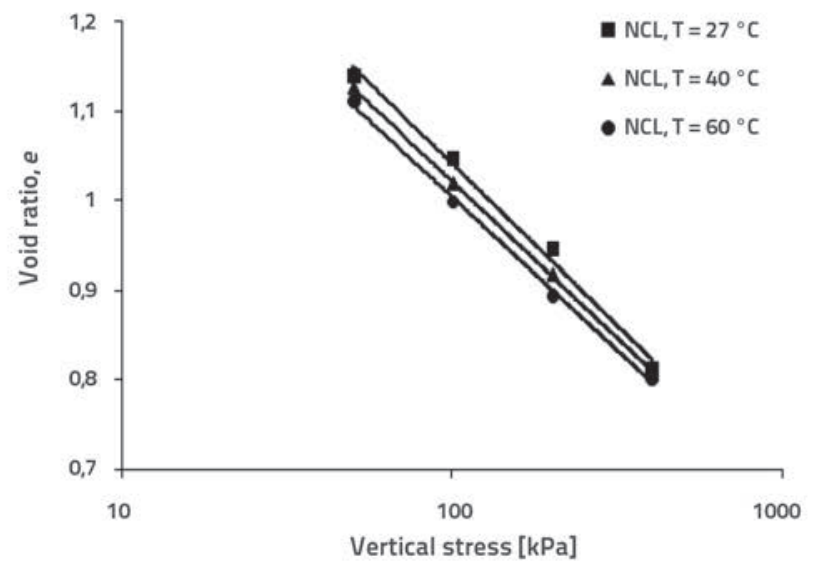

the compression caused by the applied load is controlling the soils response. The lower void ratio values for both series at higher temperatures can be explained by the produced thermal compaction phenomenon [4] or thermal hardening phenomenon [6].

Table 3. Preconsolidation stress in moist condition

\begin{tabular}{|c|c|c|c|}
\hline \multirow{2}{*}{$\begin{array}{c}\text { Soil specimen } \\
\text { (Series) }\end{array}$} & \multicolumn{3}{|c|}{ Preconsolidation stress [kPa] } \\
\cline { 2 - 4 } & $27\left[{ }^{\circ} \mathrm{C}\right]$ & $40\left[{ }^{\circ} \mathrm{C}\right]$ & $60\left[{ }^{\circ} \mathrm{C}\right]$ \\
\hline A & 81 & 65 & 50 \\
\hline B & 150 & 149 & 148 \\
\hline
\end{tabular}

Figures 5.a and 5.b show normal consolidation lines (NCL) for moist specimens of both series $A$ and $B$, respectively. $\mathrm{NCL}$ properties are given in Table 4. The temperature effect on the compression index of soil was studied by comparing $\mathrm{NCL}$ values at different temperatures. The slopes of the NCL obtained from graphs, known as the compression index $(C)$, are presented in Table 4. The results show that the compression index slightly decreases with an increase in temperature. In other words, the effect of temperature on the compression index was negligible.

Table 4. Properties of normal consolidation lines (NCLs)

\begin{tabular}{|c|c|c|c|c|}
\hline $\begin{array}{c}\text { Soil } \\
\text { specimen } \\
\text { (Series) }\end{array}$ & $\begin{array}{c}\text { Dry } \\
\text { density } \\
{\left[\mathrm{Mg} / \mathrm{m}^{3}\right]}\end{array}$ & $\begin{array}{c}\text { Tempe- } \\
\text { rature } \\
{\left[{ }^{\circ} \mathrm{C}\right]}\end{array}$ & $\begin{array}{c}\text { Best fit equation for } \\
\text { normal consolidated } \\
\text { part of compression } \\
\text { curve }\end{array}$ & $\begin{array}{l}\text { Slope } \\
\text { of } \\
N C L \\
\left(C_{c}\right)\end{array}$ \\
\hline \multirow{3}{*}{ A } & \multirow{3}{*}{1,21} & 27 & $y=-0,361 \log (x)+1,7614$ & 0,361 \\
\hline & & 40 & $y=-0,350 \log (x)+1,7224$ & 0,350 \\
\hline & & 60 & $y=-0,343 \log (x)+1,6907$ & 0,343 \\
\hline \multirow{3}{*}{ B } & \multirow{3}{*}{1,35} & 27 & $y=-0,286 \log (x)+1,5634$ & 0,286 \\
\hline & & 40 & $y=-0,276 \log (x)+1,5344$ & 0,276 \\
\hline & & 60 & $y=-0,270 \log (x)+1,5142$ & 0,270 \\
\hline
\end{tabular}

b)

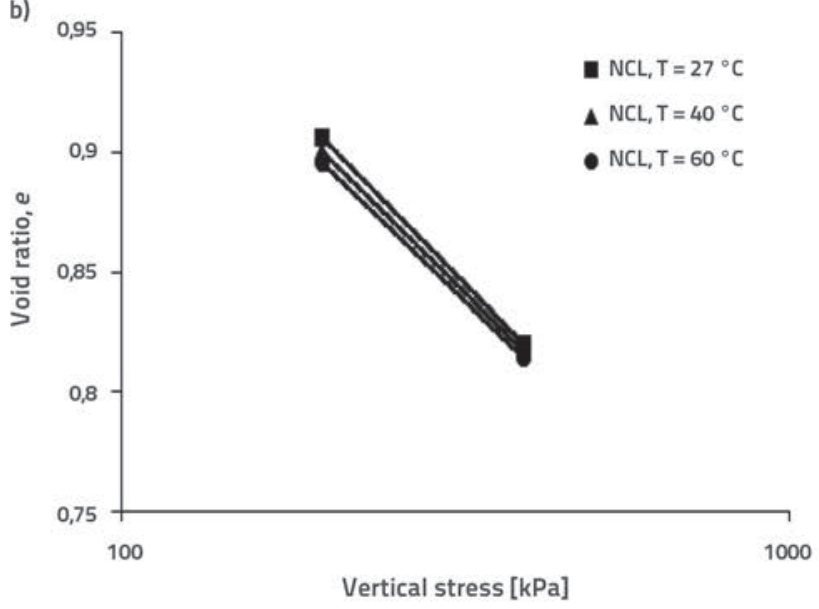

Figure 5. Normal consolidation lines (NCL) at 27,40 , and $60^{\circ} \mathrm{C}$ for moist specimens of: a) series $\mathrm{A}$; b) series $\mathrm{B}$ 


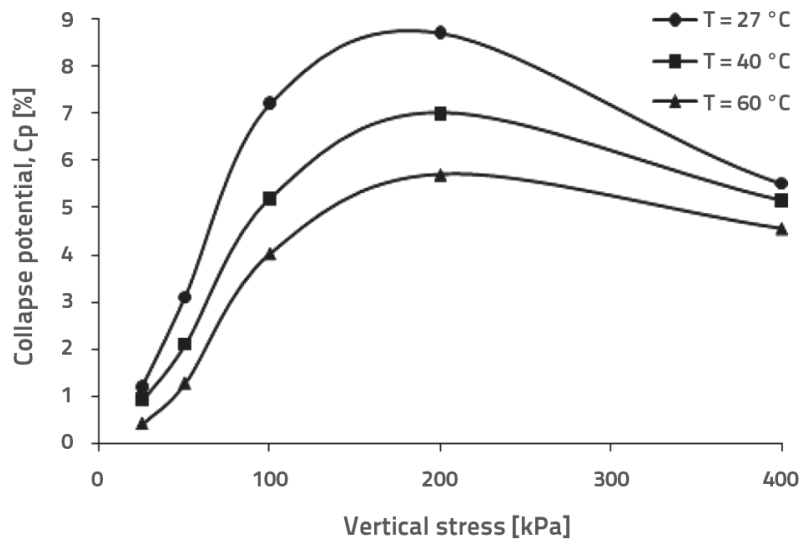

Figure 6. Collapse potential for series A specimens at 27,40 , and $60{ }^{\circ} \mathrm{C}$

The influence of temperature on the collapse potential $(C p)$ of soil samples is presented in Figures 6 and 7. It can be seen that the collapse potential of specimens decreases with an increase in temperature for both series $A$ and $B$ due to thermal compaction or thermal hardening. The reduction for looser specimens was more significant than that of denser specimens. The maximum reduction of $C p$ amounted to $3.01 \%$ and $1.25 \%$ for series $A$ and $B$, respectively.

The maximum collapse potential was observed at vertical stress of approximately $200 \mathrm{kPa}$, for both series A and B at 27 ${ }^{\circ} \mathrm{C}$. However the influence of heating on $C p$ was less obvious as the applied vertical stress increased. The collapse potential of the soil increased initially to a maximum value with an increase in vertical stress, and then it decreased at higher levels of vertical stress. Medero et al. [17] reported similar behavior for an artificial cemented soil.

\section{Conclusion}

Based on the experimental results obtained by oedometer testing of a residual granitic soil, the following main conclusions can be made:

\section{REFERENCES}

[1] Campanella, R. G., Mitchell, J. K.: Influence of temperature variations on soil behavior, Journal of Geotechnical Engineering, Division, ASCE, Vol. 94 (1968) 3, pp. 709-734.

[2] Virdi, S.P. S., Keedwell, M. J.: Some observed effect of temperature variation on soil behavior, Proceedings of International Conference on Rheology and Soil Mechanics, Coventry, 1988.

[3] Villar, M. V., Lloret, A.: Influence of temperature on the hydromechanical behaviour of a compacted bentonite, Applied Clay Science, Vol. 26 (2004), pp. 337-350.

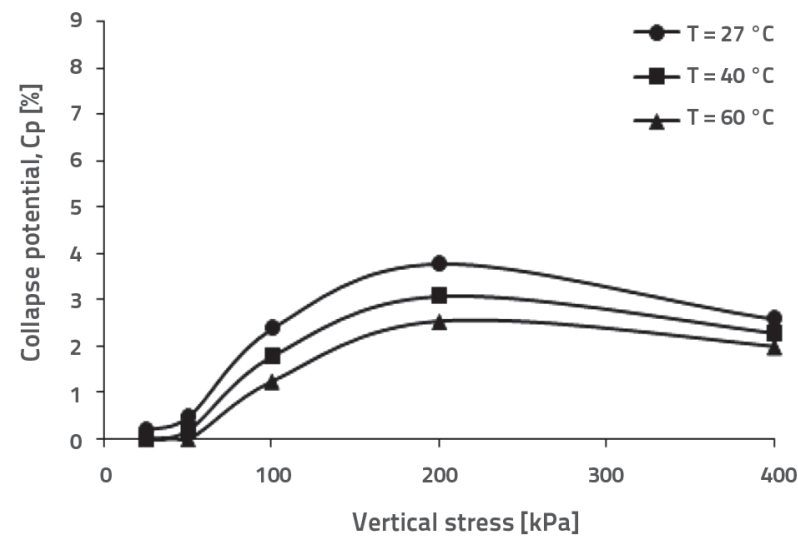

Figure 7. Collapse potential for series B specimens at 27, 40, and $60{ }^{\circ} \mathrm{C}$

- The preconsolidation stress of the residual granitic soil reduced with the rise in temperature. However, this reduction was negligible in case of denser samples.

- Normal consolidation lines (NCLs) at different temperatures were slightly moved in a parallel trend. This means that the compression index (slopes of the NCL) of the soil can be considered independent from temperature.

- The collapse potential of soil decreased with an increase in temperature. The reduction was more pronounced for looser samples than for denser samples. However, the collapse potential of samples increased up to the maximum value with an increase in vertical stress, and then it decreased at higher levels of vertical stress.

\section{Acknowledgment}

The authors would like to acknowledge the financial support given by the University Technologi Malaysia (UTM). This support is gratefully appreciated.
[4] Cekerevac, C., Laloui, L.: Experimental study of thermal effects on the mechanical behaviour of a clay, International Journal of Numerical and Analytical Methods in Geomechanics, Vol. 28 (2004), pp. 209-228.

[5] Romero, E., Villar, M. V., Lloret, A.: Thermohydro- mechanical behaviour of two heavily overconsolidated clays, Engineering Geology, Vol. 81 (2005) 3, pp. 255-268.

[6] Haghighi, A., Medero, G., Woodward, P., Laloui, L.: Effect of temperature on collapse potential of kaolin clay, Unsaturated Soils, Alonso \& Gens eds. ๑ 2011 Taylor \& Francis Group, London, pp. 543-548, 2011. 
[7] Tang, A. M., Cui, Y. J., Barnel, N.: Thermomechanical behaviour of a compacted swelling clay, Geotechnique, Vol. 58 (2008) 1, pp. 44-54.

[8] Francois, B., Laloui, L.: ACMEG-TS: A constitutive model for unsaturated soils under non-isothermal conditions, International Journal of Numerical and Analytical Methods in Geomechanics, Vol. 32 (2008), pp. 1955-1988.

[9] Lawton, E. C., Fragaszy, R. J., Hetherington, M. D.: Review of wetting-induced collapse in compacted soil, Journal of Geotechnical Engineering, ASCE, Vol. 118 (1992) 9, pp.13761394.

[10] Pereira, J. H. F., Fredlund, D. G.: Volume change behavior of collapsible compacted gneiss soil, Journal of Geotechnical and Geoenvironmental Engineering, Vol. 126 (2000), pp. 907-916.

[11] Rao, S. M., Revanasiddappa, K.: Influence of cyclic wetting drying on collapse behavior of compacted residual soil, Journal of Geotechnical and Geological Engineering, Vol. 24 (2006), pp. 725734.
[12] British Standards Institution, BS 1377:1990: Part 2: Classification tests, London, 1990.

[13] British Standards Institution, BS 1377:1990: Part 4: Compactionrelated tests, London, 1990.

[14] Jennings, J.E., Knight, K.: The additional settlement of foundations due to a collapse of structure of sandy subsoils on wetting, Proc., Int. Conf. on Soil Mechanics and Foundation Engineering, Vol. 3, Butterworths, London, pp. 316-319, 1957.

[15] American Society for Testing and Materials (ASTM), Test method for measurement of collapse potential of soils, ASTM standards, Philadelphia, 2003.

[16] Lloret, A., Villar, M. V., Sanchez, M., Gens, A., Pintado, X., Alonso, E. E.: Mechanical behavior of heavily compacted bentonite under high suction changes. Geotechnique, Vol. 53 (2003) 1, pp. 27-40.

[17] Medero, G. M., Schnaid, F., Gehling, W. Y. Y.: Oedometer behavior of an artificial cemented highly collapsible soil, Journal of Geotechnical and Geoenvironmental Engineering, Vol. 135 (2009) 6, pp. 840-843. 